\title{
Responses of Estuarine Infauna to Disturbance. I. Spatial and Temporal Variation of Initial Recolonization
}

\author{
Roman N. Zajac and Robert B. Whitlatch \\ Department of Marine Sciences and Biological Sciences Group, The University of Connecticut, Marine Research Laboratory,
} Noank, Connecticut 06340, USA

\begin{abstract}
Responses to disturbance of estuarine infauna were studied to test the hypothesis that seasonality, the estuarine environmental gradient and sediment composition would significantly affect recolonization. The study was conducted in a small estuary located in southeastern Connecticut, USA, using controlled disturbance experiments and sampling of the ambient infauna. Species composition in experimental plots and ambient sediments usually did not differ, either on a seasonal or areal basis. Numerically dominant species usually included the polychaetes Streblospio benedicti, Capitella spp. and Polydora ligni, and the oligochaete Peloscolex gabriellae. Other species included the polychaetes Scoloplos fragilis, Hobsonia florida and Nereis virens, the hemichordate Saccoglossus kowaleski, and the amphipods Microdeutopus gryllotalpa and Corophium insidiosum. At times, densities of these species exceeded or were equivalent to dominant species densities in ambient sediments and experimental plots. There were usually significant differences in recolonization and ambient population dynamics due to seasonality and estuarine position. The effects of sediment composition on recolonization patterns of the various species were generally not significant. Seasonal trends in ambient and recolonization species densities were similar, with the highest responses to disturbance in the spring and summer. As ambient densities declined during the fall and winter, responses to disturbance did likewise. On an areal basis, the highest responses to disturbance occurred in the middle and upper portions of the estuary. Ambient densities followed a similar pattern, but peak densities in the early spring (May, 1979) were found in the lower portion of the estuary. Based on differences between ambient and recolonization population densities, only 1 species, Polydora ligni, exhibited a regular opportunistic response. Other species exhibited opportunistic responses, but in only 1 or 2 mo during the study. It is apparent, therefore, that species responses to disturbance were quite variable and no general pattern of recolonization could be applied to Alewife Cove with respect to seasonality and estuarine position. Due to this variation, and the historical component involved in recolonization of disturbed habitats, hypotheses correlating species responses to disturbance with life history adaptations may not be generally applicable to estuarine soft-bottom communities.
\end{abstract}

\section{INTRODUCTION}

Disturbance, defined as any stochastic event initiating species populational change either from densityindependent mortality and/or a change in the resource base of the community, has been shown to be an important factor influencing community structure in many environments (e.g. Connell and Slatyer, 1977; Whittaker and Levin, 1977; Paine and Levin, 1981). Johnson (1973) hypothesized that marine benthic communities are 'continually varying in response to a history of disturbance . . . and therefore different parts are at different levels of succession'.
The effects of disturbance on marine infaunal communities, and the successional changes that ensue have been studied extensively (e.g. Dean and Hasking 1964; Leppakowski, 1969; Grassle and Grassle, 1974 Guerin and Masse, 1976; McCall, 1977; Richter and Sarnthien, 1977; Simon and Dauer, 1977; Wolff et al., 1977; Arntz and Rumohr, 1978; Pearson and Rosenberg, 1978; Rhoads et al., 1978; Rumohr, 1978; Sanders et al., 1980; Santos and Simon, 1980a, b; Woodin, 1981). While similar successional patterns have been observed in distinct soft-bottom environments, little is known about how spatial and temporal differences in abiotic and biotic factors within an environment affect 
community establishment. Most investigations have followed species and community responses to disturbance which has occurred at only 1 point during the year and/or within only 1 type of habitat in a particular environment. Studies examining the influence of environmental heterogeneity (e.g. Grassle and Grassle, 1974; Dauer and Simon, 1976; Guerin and Masse, 1976; Richter and Sarnthien, 1977; Pearson and Rosenberg, 1978; Santos and Simon, 1980b) indicate that species and community responses to disturbance can be affected by a variety of biotic and abiotic factors. Further, few concurrent comparisons of disturbed sites with ambient (undisturbed) conditions are available (McCall, 1977; Rhoads et al., 1977, 1978; Conner and Simon, 1979) and in some studies which monitored undisturbed ('control') sites, differing sampling methodologies preclude definitive comparison (e.g. McCall, 1977; Rhoads et al., 1978). Such comparisons are crucial to ascertaining how responses to disturbance differ from prevailing infaunal dynamics, and when (or if) the disturbed habitat begins to approximate ambient conditions.

This study examines patterns of initial recolonization in an estuarine infaunal community. Short-term recolonization experiments were performed to determine to what extent spatial and temporal fluctuations in physical and biological factors, and sediment composition, would cause variations in this stage of succession. The degree of opportunistic behaviour (sensu Thistle, 1981) exhibited by species found during the study was also assessed.

\section{MATERIALS AND METHODS}

The study was conducted in Alewife Cove $\left(72^{\circ} 07^{\prime} \mathrm{W}\right.$, $\left.41^{\circ} 21^{\prime} N\right)$, adjacent to the Thames River, southeastern Connecticut, USA (Fig. 1). The Cove is a small (17 ha), shallow estuary entertaining tidal exchange with Long Island Sound. The primary source of freshwater is Fenger Brook watershed (802 ha), although an important secondary source can be lateral runoff (Welsh et al., 1978).

Data were collected from ambient infaunal communities and in-situ recolonization experiments from June 1978 to July 1979. In this study recolonization is defined as the initial stages of community establishment (i.e. population densities 4 to $6 \mathrm{wk}$ after controlled disturbance). Spatial variability in recolonization was studied by deploying experimental plots at 3 shallow, subtidal study sites in the Cove: Station I (SI) in the lower reach. Station II (SII) in the middle basin, and Station III (SIII) in the upper basin (Fig. 1). Study sites corresponded to physical and chemical divisions of the Cove (Table 1). Temporal variability was examined by

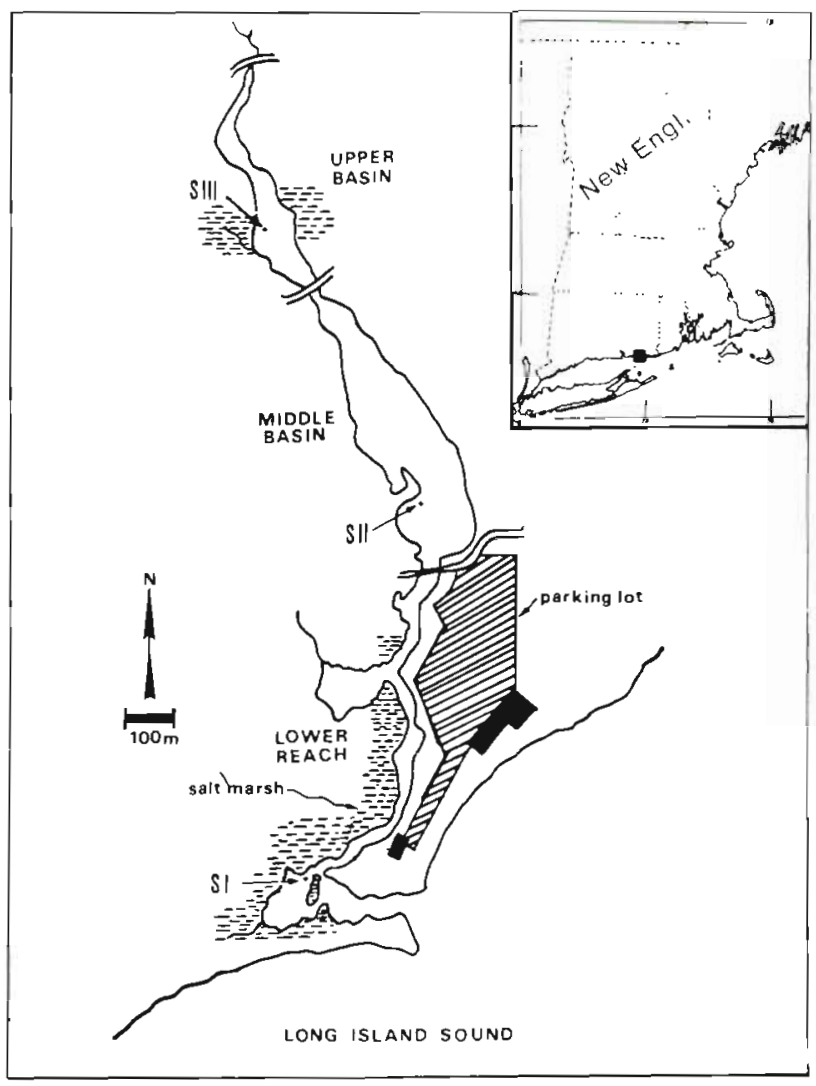

Fig. 1. Location of Alewife Cove in southeastern Connecticut, USA (insert). Arrows pointing to Xs denote locations of the 3 study sites (SI, SII, SIII) in the estuary

deploying plots at each station for 9 separate exposure periods (Table 2). To determine the effect of sediment composition on recolonization, each set of experiments was performed using fine sand (sand) and silt (mud) sediments. There were 2 replicate plots for each station-time-sediment treatment. Ambient sediments near the experimental arrays were sampled on each of the 9 recolonization sampling dates, and also in March 1979. Each set of samples included 5 randomly positioned cores from the ambient sediments and each experimental plot.

Disturbance was simulated by filling experimental plots (plastic buckets, $20 \mathrm{~cm}$ height, $0.229 \mathrm{~m}^{2}$ surface area) with defaunated sediments. Sediments were collected from Alewife Cove and silt-clay content ( $\%$ total dry weight) was $10 \%$ and $80 \%$ for sands and muds, respectively. Defaunation was accomplished by allowing the sediments to remain in covered plastic buckets for approximately $1 \mathrm{wk}$ or longer; they were then washed with freshwater through $2 \mathrm{~mm}$ and $1 \mathrm{~mm}$ sieves for sands and muds, respectively. Samples were checked periodically to ensure complete defaunation and no living organisins were ever found. 
Table 1. Summary of physical characteristics in Alewife Cove

\begin{tabular}{|c|c|c|c|c|c|c|}
\hline \multirow[b]{2}{*}{ AREA } & \multirow[b]{2}{*}{$\begin{array}{l}\text { Mean depth }{ }^{1} \\
\quad(\mathrm{~cm})\end{array}$} & \multicolumn{3}{|c|}{ Parameter } & \multirow[b]{2}{*}{$\begin{array}{l}\text { Seasonal } \\
\text { nutrient } \\
\text { patterns }\end{array}$} & \multirow[b]{2}{*}{$\begin{array}{l}\text { Sediments } \\
\text { and } \\
\text { sedimentation }^{1.3}\end{array}$} \\
\hline & & $\begin{array}{l}\text { Salinity } \\
\text { range } \\
(\% \%)\end{array}$ & Flow $^{1}$ & $\begin{array}{l}\text { Changes } \\
\text { in salinity } \\
\text { structure }\end{array}$ & & \\
\hline $\begin{array}{l}\text { Lower Reach } \\
\text { (SI) }\end{array}$ & 35 & $20-32$ & Tidal & Negligible & $\begin{array}{l}\text { Marine dominated } \\
\text { (Long Island } \\
\text { Sound) }\end{array}$ & $\begin{array}{l}\text { Fine sand, } \\
\text { ? }\end{array}$ \\
\hline $\begin{array}{l}\text { Middle Basin } \\
\text { (SII) }\end{array}$ & 98 & $13-30$ & Mixed & Moderate & $\begin{array}{l}\text { Mixed, in spring } \\
\text { similar to upper } \\
\text { basin, otherwise } \\
\text { similar to lower } \\
\text { reach }\end{array}$ & $\begin{array}{l}\text { Silt, } \\
\text { relatively } \\
\text { constant rates }\end{array}$ \\
\hline $\begin{array}{l}\text { Upper Basin } \\
\text { (SIII) }\end{array}$ & 43 & $0-30$ & $\begin{array}{l}\text { Mixed, } \\
\text { primarily } \\
\text { affected by } \\
\text { freshwater } \\
\text { discharge }\end{array}$ & Large & $\begin{array}{l}\text { 'Distinctly different } \\
\text { from marine or } \\
\text { freshwater patterns' }\end{array}$ & $\begin{array}{l}\text { Silt, large } \\
\text { seasonal } \\
\text { fluctuations }\end{array}$ \\
\hline $\begin{array}{l}{ }^{1} \text { Welsh et al. } \\
{ }^{2} \text { Herring }(197 \\
{ }^{3} \text { Welsh and } \mathrm{V}\end{array}$ & $\begin{array}{l}\text { 978) } \\
\text { itlatch (1980) }\end{array}$ & & & & & \\
\hline
\end{tabular}

Table 2. Sampling schedule of recolonization plots and ambient sediments. Initial deployment was on June 13,1978; plots sampled in May were deployed March 30, 1979. Duration of exposure is shown in days (d). Sample designations used in the text are shown in parentheses

\begin{tabular}{|c|c|c|}
\hline $\begin{array}{l}\text { Sampling/ } \\
\text { deployment }\end{array}$ & $\begin{array}{l}\text { Recolonization } \\
\text { plots }\end{array}$ & $\begin{array}{l}\text { Ambient } \\
\text { sediments }\end{array}$ \\
\hline $6-13-78$ & - & \\
\hline $6-27-78$ & $14 \mathrm{~d}$ (June) ${ }^{*}$ & + \\
\hline $7-13-78$ & $30 \mathrm{~d}$ (July) & + \\
\hline $8-11-78$ & 29 d (August ${ }^{*}$ & + \\
\hline $9-15-78$ & $35 \mathrm{~d}$ (September) & + \\
\hline $11-1-78$ & $46 \mathrm{~d}$ (November) & + \\
\hline $12-28-78$ & $57 \mathrm{~d}$ (December) & + \\
\hline $3-22-79$ & & + \\
\hline $3-30-79$ & $\cdot$ & \\
\hline $5-3-79$ & $34 \mathrm{~d}($ May) & + \\
\hline $6-5-79$ & $34 \mathrm{~d}$ (June) " & + \\
\hline $7-20-79$ & $44 \mathrm{~d}^{(J u l y)^{\circ}}$ & + \\
\hline \multicolumn{3}{|c|}{$\begin{array}{l}\text { - Fresh plots put into place } \\
+ \text { Ambient sediments sampled }\end{array}$} \\
\hline
\end{tabular}

Experimental plots were placed directly into the sediments at SI with tops approximately flush with the sediment suface. At SII and SIII, plots were deployed into wooden frames pushed into the silt bottoms as far as possible. Plots at these stations protruded approximately $10 \mathrm{~cm}$ above the sediment surface. Differences in deployment were to avoid human disturbance at $\mathrm{SI}_{1}$ and provide easier retrieval of samples at SII and SIII.
Plot position within each experimental array was randomized at the beginning of the study and remained the same throughout the study.

Samples were collected using cores $(3.4 \mathrm{~cm}$ inside diameter) pushed $20 \mathrm{~cm}$ into the sediment. Samples were brought to the laboratory and washed through a $297 \mu \mathrm{m}$ mesh sieve. Sample residues were fixed in $10 \%$ buffered formalin, transferred to $70 \%$ ethanol, and stained with rose bengal. All samples were sorted under a dissecting microscope and all organisms identified to species. Members of the genus Capitella were combined as Capitella spp. owing to the morphologic similarities in this suite of sibling species (Grassle and Grassle, 1977). A total of 630 cores were processed.

Two-way analyses of variance (ANOVA) were used to test for differences in total and individual species densities between sites and sampling periods (i.e. space versus time) for ambient and recolonization data. If these proved to be significant $(p<.05)$, between-site differences within a sampling period, and temporal differences within a site, were further analyzed using one-way ANOVAs and a posteriori t-test matrices. Differences between sand and mud recolonization, and ambient sediments were tested for each sampling period using one-way ANOVAs and a posteriori t-test matrices. All statistical analyses were performed using standard programs provided in Dixon and Brown (1979). Clustering programs (Dixon and Brown, 1979) were also used to measure the similarity of species abundance fluctuations in ambient sediments and responses to the simulated disturbances. The t-test 
matrix tests are multiple comparisons of sample means similar to Fisher Least Significant Difference (LSD) tests; they are appropriate for the statistical analyses for which they were used (Snedecor and Cocharan, 1974). A significance level of $\mathrm{p}<.05$ was used for all statistical tests and data were transformed, $\log 10(X+1)$, prior to analyses.

\section{RESULTS}

Thirty taxa were collected during the course of the study (Zajac, 1981). Of these, 16 species were selected for further analysis based on at least 2 occurences in either set of ambient or recolonization samples.

\section{Ambient Community}

The spatial distribution of species within Alewife Cove was relatively uniform. Seven species (Streblospio benedicti, Capitella spp., Peloscolex gabriellae, Polydora ligni, Eteone heteropoda, Nereis virens, Gammarus mucronatus) were found at all stations and only 4 species were found at 1 station only (Spio setosa, Scolecolepides viridis, and Saccoglossus kowaleski at SI, Hobsonia florida at SIII).

Seasonality, position in the estuary, and the interaction between these 2 factors caused highly significant differences in ambient total abundance $(p<0.001$ for each effect and the interaction, two-way ANOVA). Further, there were significant differences in total abundance between sampling periods at each station $(p<.01$, one-way ANOVA), and within a sampling period there were significant differences between stations, except in March and July 1979 ( $p<.05$, one-way ANOVA). Although ambient total abundance patterns were variable (Fig. 2), trends during some sampling periods were evident throughout the estuary. This was especially evident in the spring and early summer, 1979, when sharp increases in abundance occurred at each station, but were staggered at approximately one month intervals.

At SI and SII, late spring and summer samples had higher abundances than samples taken at other times ( $p<.05$, a posteriori t-tests). Abundances at SII in June 1979 were significantly higher than at any other time at this location. At both SI and SII, abundances from August to March were not different. In contrast, total abundance at SIII was not as temporally variable, with significant differences occurring only between a few months ( $\mathrm{p}<.05$, a posteriori t-tests).

Between-station comparisons indicated that at least once during the study period each station supported a significantly higher total abundance of infauna than

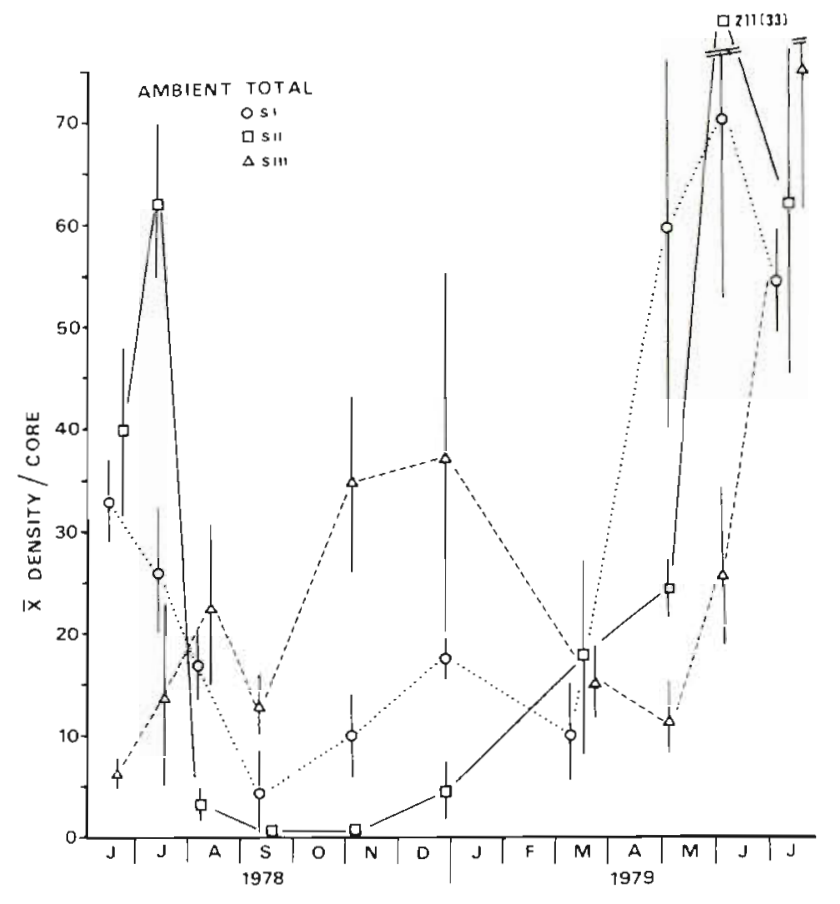

Fig. 2. Ambient total density fluctuations in Alewife Cove (mean \pm standard error). No samples were taken in October 1978, and January, February and April 1979

the other 2 ( $\mathrm{p}<.05$, a posteriori t-tests). Total abundance at SI was greatest in May, at SII in July 1978 and June 1979, and at SIII from September to December. At these times there were no significant differences in total abundance between the other two stations, and at no time was total abundance different at all 3 study sites.

Most individual species abundances were also spatially and temporally variable (Fig. 3). Significant differences in abundance for 12 of the 16 species (Streblospio benedicti, Capitella spp., Peloscolex gabriellae, Polydora ligni, Hobsonia florida, Scoloplos fragilis, Eteone heteropopda, Nereis virens, Saccoglossus kowaleski, Gemma gemma, Microdeutopus gryllotalpa, and Edotea triloba) were attributed to time and position, and the interaction between them ( $\mathrm{p}<.05$, twoway ANOVAs). No significant differences in abundance between stations and sampling periods were exhibited by Scolecolepides viridis, Corophium insidiosum, and Gammarus mucronatus, while densities of Spio setosa were significantly different only with respect to position in the estuary.

In many cases individual species abundance patterns approximated seasonal and areal trends of total abundance, especially in spring and summer 1979 , when a majority reached maximum abundance. These peaks coincided with increased reproductive activity and many of the individuals collected during this 

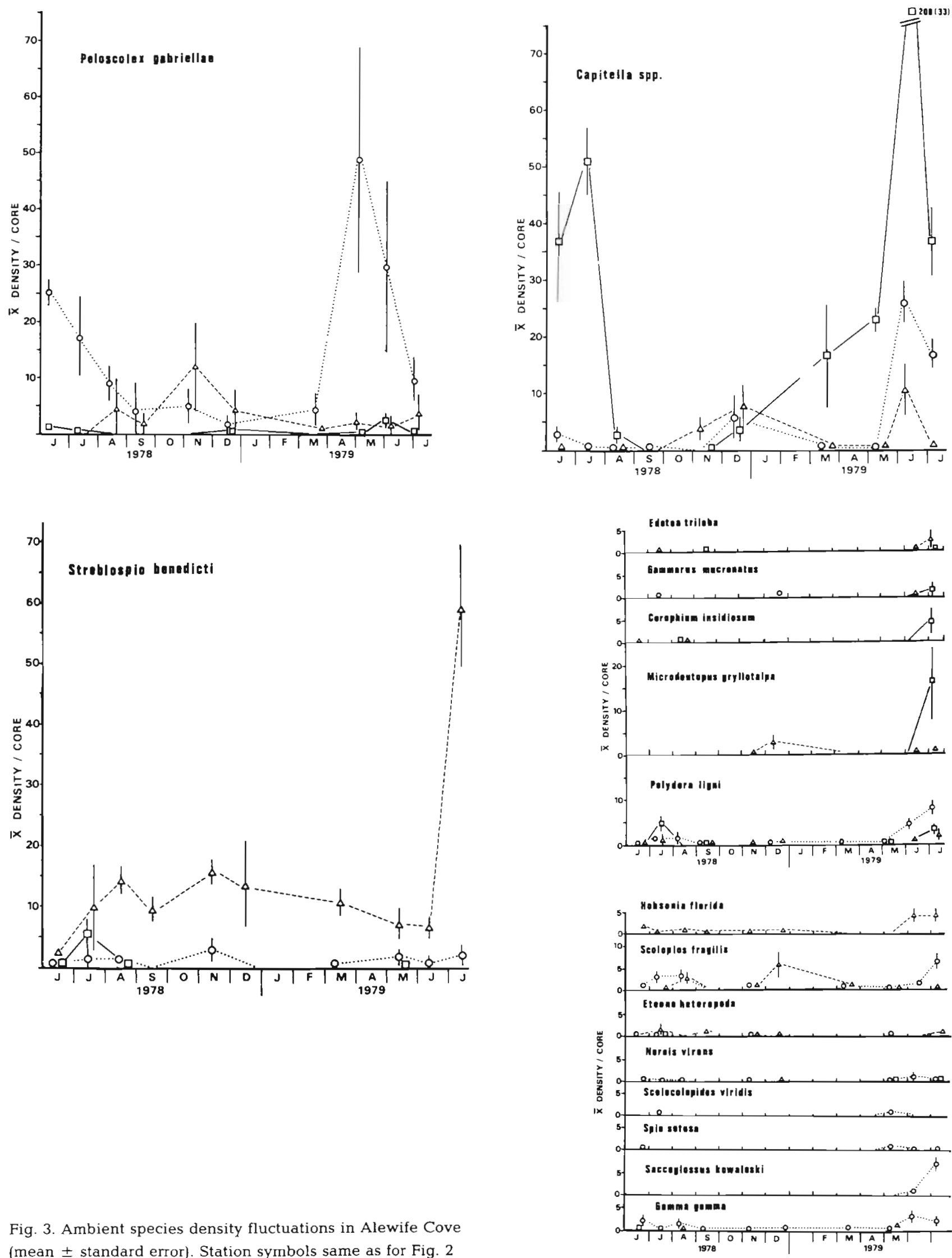

Fig. 3. Ambient species density fluctuations in Alewife Cove (mean \pm standard error). Station symbols same as for Fig. 2 
period were larvae and/or juveniles (personal observations). Three species were found to be numerically dominant at particular stations: Peloscolex gabriellae at SI, Capitella spp. at SII, and Streblospio benedicti at SIII. Ambient total abundance fluctuations, in large part, reflected density fluctuations of these three species, which are detailed below

Peloscolex gabriellae attained highest densities during spring and summer at SI (Fig. 3). Abundances at SI were usually significantly higher than at SII and SIII $(p<.05$, one-way ANOVA), and differences between sampling periods occurred at SI and SII but not at SIII.

Although Capitella spp. dominated at SII, its density fluctuated markedly, peaking during the spring and summer (Fig. 3). Sharp increases at SI and SIII were also observed in June 1979. This species was usually most abundant at SII and densities were significantly higher than at SI and SIII ( $p<.05$, a posteriori t-tests), except in September and December (no significant differences), and November (SIII densities significantly higher than SI and SII). Significant differences between sampling periods were found at each study site $(p<.05)$, one-way ANOVA).

In contrast to the temporal patterns exhibited by Peloscolex gabriellae and Capitella spp. at sites where they were most abundant, Streblospio benedicti at SIII showed little variation in abundance throughout most of the study period. Although a one-way ANOVA indicated highly significant differences between sampling periods $(p<.001)$ in this area, an a posteriori t-test matrix showed that this result was due to 2 mo in particular (June 1978 and July 1979). At SI and SII it was found at relatively lower densities.

Classification analysis of the ambient species data (Fig. 4) revealed that species groups were formed primarily on the basis of spatial similarities and secondarily by seasonal patterns of fluctuation within a station. The largest cluster (B) consisted of 6 species that either co-occurred in greatest abundance at SI, or were restricted to SI. The cluster consisted of 2 smaller groups of species which exhibited similar patterns of seasonal fluctuation. One group contained species whose highest abundances were found in June 1979 (Peloscolex gabriellae, Nereis virens and Gemma gemma), while the other group included species displaying population increases at SI during July 1979 , and were generally present during most of the study period (Polydora ligni, Saccoglossus kowaleski, Scoloplos fragilis). Cluster B1, an outlier of cluster B, consisted of only 1 species, Capitella spp. The outlying position reflected its marked population fluctuations at SI and SII. Its addition to cluster B was probably due to a coincident period of peak population abundances in the spring and summer of 1979

Cluster A included the dominant species at SIII,

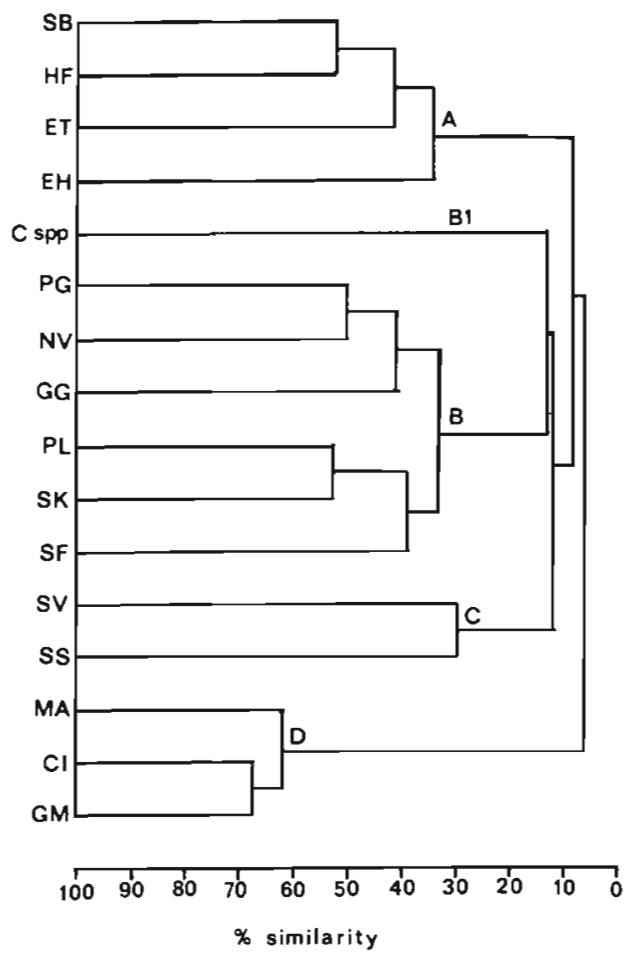

Fig. 4. Similarity dendrogram of species density fluctuations in ambient sediments. Species are clustered by the similarity of their occurrence and population density at the three study sites through time, based on data from all ambient cores. The criterium for combining clusters was average linkange. Groups were determined by visual inspection of the dendrogram. SB Streblospio benedicti, C spp Capitella spp., PG Peloscolex gabriellae, PL Polydora ligni, HF Hobsonia florida, SF Scoloplos fragilis, EH Eteone heteropoda, NV Nereis virens, SV Scolecolepides viridis, SS Spio setosa, SK Saccoglossus kowaleski, GG Gemma gemma, MA Microdeutopus gryllotalpa, CI Corophium insidiosum, CM Gammarus mucronatus, ET Edotea triloba

Streblospio benedicti and Edotea triloba, Hobsonia florida and Eteone heteropoda. These species exhibited peak densities during June and/or July 1979, at SIII (Fig. 3). Highest similarity was found in cluster D which was composed of amphipods (Microdeutopus gryllotalpa, Corophium insidiosum, and Gammarus mucronatus). These species were absent during most of the study period but were found in relatively high densities at SII in July 1979, especially Microdeutopus gryllotalpa. Cluster C comprised 2 species (Scolecolepides viridis, Spio setosa) which were found only at SI during 2 and 4 sampling periods, respectively (Fig. 3).

\section{Recolonization}

No species exotic to Alewife Cove settled in the experimental plots at any of the study sites. Overall species composition was similar to ambient sediments, 
and most species were found in experimental plots at each study site at least once during the study period (Fig. 6). Four species did not settle at certain sites: Scolecolepides viridis and Spio setosa at SIII, Saccoglossus kowaleski at SII, and Hobsonia florida at SI and SII. Localized recolonization of these 4 species was similar to their localized distributions in ambient sediments, while estuarine-wide occurrence in ambient sediments of the other species coincided with recolonization of sand and/or mud plots throughout the Cove.

Patterns of Total Abundance

Total recolonization, in both sand and mud plots, varied significantly on a spatial and temporal basis (two-way ANOVA, $p<0.001$ ). However, within a sampling period there were few cases of significant differences between replicate plots (Zajac, unpubl. data available upon request), indicating that despite large areal and seasonal differences, recolonization within a habitat and a particular time was relatively uniform in disturbed patches.

In general, total recolonization was greatest during the spring and summer months at all stations and sediment types (Fig. 5). Responses declined at SI and

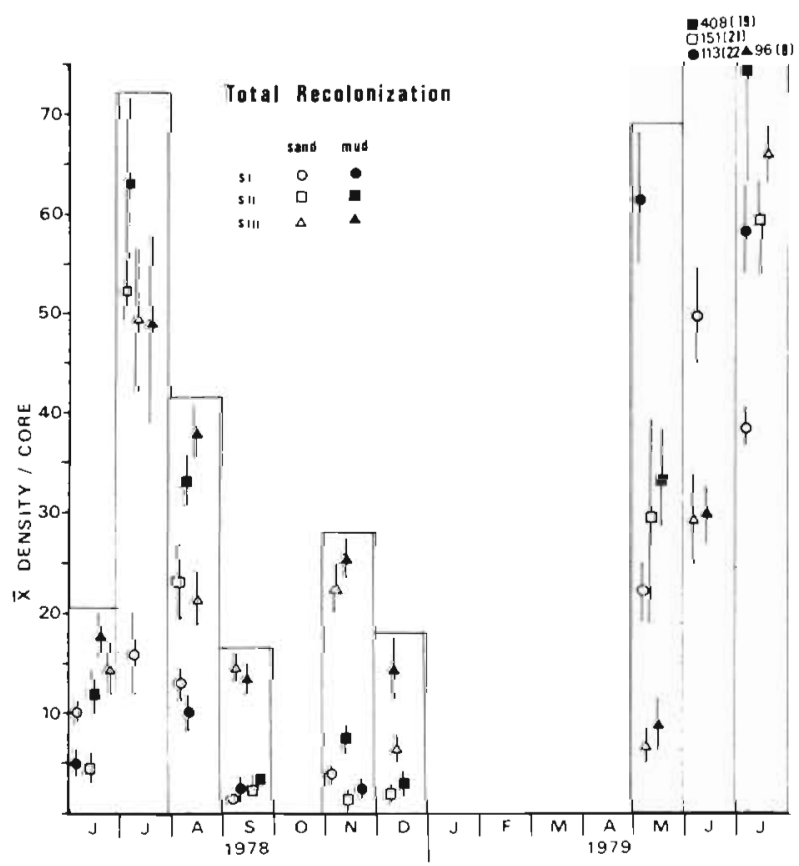

Fig. 5. Total recolonization densities in Alewife Cove (mean \pm standard error). The histogram surrounding each month's data is used for clarity

SII during fall and early winter, while at SIII recolonization continued to be relatively high. The lowest recolonization at SIII occurred in May. While the initia- tion of an active spring-summer period in 1979 was evident by May at SI and SII, responses at SIII did not begin to increase until June. The highest responses at SI and SII were found in June 1979 and at SIII in July 1979.

Between-station differences in total recolonization were significant during all of the sampling periods, except December 1978 in sand plots and July 1978 in mud plots (one-way ANOVA, p<.05). At both of these times full sets of samples were not obtained at SI. In July 1978 mud plots were lost due to human disturbance, and in December neither sand or mud plots were sampled due to ice formation. Temporal differences in total recolonization were also highly significant within each station ( $\mathrm{p}<.05$, one-way ANOVA). Specific patterns of spatial and temporal variation were analysed in detail elsewhere (Zajac, 1981), but on an overall basis recolonization was usually significantly higher at SII and/or SIII than at SI, and temporal variation in recolonization was greatest at SI and progressively decreased at SII and SIII.

\section{Species Recolonization Patterns}

Species' responses to disturbances were highly variable in both sands and muds (Fig. 6). Two-way ANOVAs showed that significant differences in species-specific recolonization could be attributed to both estuarine position and seasonality $(\mathrm{p}<.05)$. The exceptions to this pattern were Spio setosa, which was found only once in sand plots (July 1978) and mud plots (May 1979), Gemma gemma, which exhibited no differences with respect to position in the estuary in mud plots, and Gammarus mucronatus, which exhibited significant differences only due to seasonality in sand plots. Overall, highest recolonization abundances were attained by species which numerically dominated ambient sediments (Streblospio benedicti, Capitella spp. and Peloscolex gabriellae).

Streblospio benedicti exhibited significant temporal differences in response both within and between sites $(p<.01$, one-way ANOVAs). Recolonization was usually higher $(p<.05, a$ posteriori t-tests) at SIII than at the other study sites (Fig. 6). While responses of this spionid declined during fall and early winter at SI and SII, at SIII Streblospio benedicti continued to settle into disturbed plots in relatively high densities. Its overall pattern at SIII represented the longest sustained high density response to disturbance observed during the course of the study. At SII significant peaks occurred also in August 1978 and July 1979, while at SI a significant response occurred only in August 1978.

Capitella spp. also displayed a highly variable recolonization pattern (Fig.6), recolonizing in high 

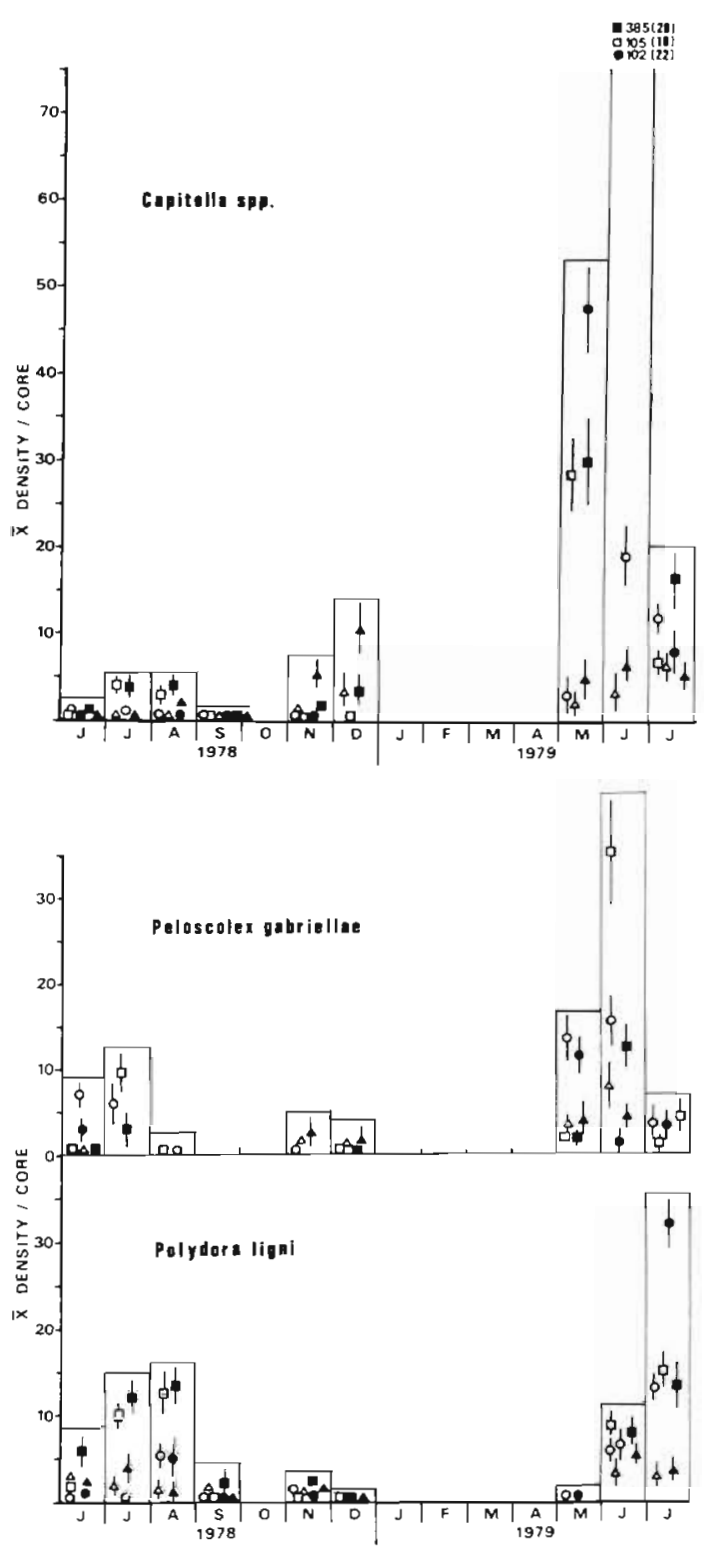

Fig. 6. Species recolonization densities in Alewife Cove (mean \pm standard error). Station and sediment symbols as in Fig. 5. When no individuals were found in a particular treatment the corresponding symbol was not included in the plot(s)
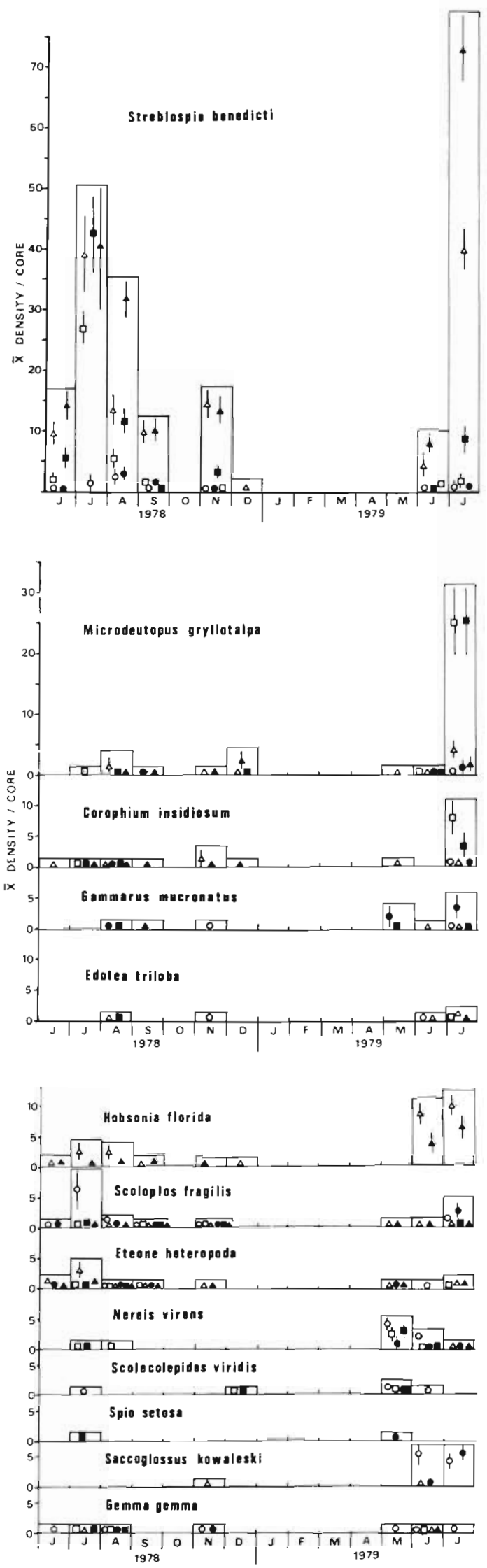
densities only during the spring and summer of 1979. Prior to this time (June-December 1978) recolonization was relatively low at each station. However, significant increases occurred at SIII in November and December and abundance also rose sharply in May. The highest pulse of larval settlement into the experimental plots during the entire study was exhibited by Capitella spp. in June 1979, at SI (muds) and at SII (sands and muds)

Recolonization by Peloscolex gabriellae was usually greatest at SI and SII (Fig. 6). Regular settlement into the experimental plots at SII did not begin until November and significant peaks occurred in May and June 1979 (a posteriori t-tests, $p<.05$ ). At SI and SII recolonization densities peaked in the spring and summer of 1979: in May at SI, and in June at SII. These peaks accounted for the highly significant seasonal differences at these stations $(p<.001$, one-way ANOVAs).

The spionid Polydora ligni also recolonized at high densities on a fairly regular basis (Fig. 6). Initially, highest responses occurred at SII and were significantly greater than at SI and SIII $(p<.05)$. Responses were low from September through May. Recolonization increased at all stations during June 1979 and peaked in July 1979. At this time, densities at SII were equivalent to the previous summer, but at SI recolonization densities were significantly higher than previously found at this location. Responses at SIII were relatively low during the entire study period, and usually significantly lower than at SI and SII.

Other species also recolonized the plots in relatively high densities. For example, Scoloplos fragilis was the most abundant species in sand plots at SI in July 1978 (Fig. 6). Relatively high numbers of Nereis virens in May, and Saccoglossus kowaleski in June and July 1979, also occurred at SI. At SII, Microdeutopus gryllotalpa and Corophium insidiosum were abundant in July 1979. At SIII, Hobsonia florida was the most abundant colonist in sand plots in June 1979, and continued to respond in high densities the following July (Fig. 6).

Classification analysis further compared recolonization patterns. Six clusters were generated (Fig. 7), all at low levels of similarity, with the clustering pattern reflecting highly significant species-specific areal and seasonal interaction obtained previously.

Cluster A comprised 4 species which recolonized primarily at SIII. Streblospio benedicti was included within this group despite its significant responses at SII during the summer of 1978.

Species in Clusters B and C exhibited recolonization mainly at SI and SII. The clusters are separated on the basis of time and place of peak response. For example, species in Cluster B recolonized primarily in May and/ or June 1979, while species forming Cluster C were

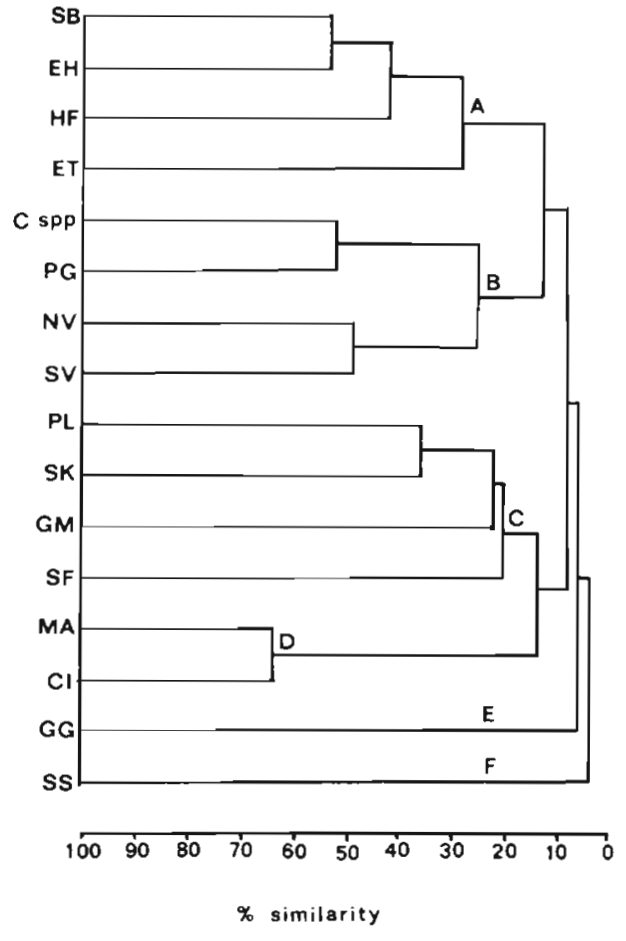

Fig. 7. Similarity dendrogram of species recolonization following disturbance. For each species, data from all sand and mud core samples were combined and used in the analysis Clustering method and species symbols same as for Fig. 4.

found at highest recolonization densities primarily in July 1979. Polydora ligni and Scoloplos fragilis also exhibited significant peaks in July 1978 and August at SII, and in July 1978 at SI, respectively. Saccoglossus kowaleski and Gammarus mucronatus responded on short-term basis only during the spring and summer of 1979

Cluster D comprised two amphipod species which recolonized at low densities during most of the study, except in July 1979 at SII. The remaining clusters, E and F, included Gemma gemma and Spio setosa respectively. Spio setosa was a poor recolonizer at all stations and was found only twice in the short-term plots at very low densities. Gemma gemma recolonized consistently, but also at low densities.

\section{Sediment Effects, Comparisons to Ambient Dynamics}

In general, there were few significant differences in total and species-specific recolonization between sands and muds, and in many cases these were not significantly different from total ambient infaunal densities (Table 3). Exceptions to this trend occurred only during periods of very high response when higher densities of infauna colonized mud plots. For example, 
Table 3. Results of one-way ANOVAs testing density differences between ambient sediments (A), sand recolonization (S) and mud recolonization (M) plots. Corresponding a posteriori t-test matrix results are presented below the ANOVA entries

\begin{tabular}{|c|c|c|c|c|c|c|c|c|c|}
\hline Species & Jun & Jul & Aug & Sep & $\begin{array}{l}10 \mathrm{nth} \\
\text { Nov. }\end{array}$ & Dec & May & Jun & Jul \\
\hline Streblospio benedicti & $\underline{\dot{M S A}}$ & $\begin{array}{c}\cdots \\
\text { SMA }\end{array}$ & $\begin{array}{c}\cdots \\
\mathrm{MSA}\end{array}$ & NS & NS & NS & $\begin{array}{c}\cdots \\
\text { SMA }\end{array}$ & NS & NS \\
\hline Capitella spp. & $\begin{array}{c}\cdots \\
\underline{S M A}\end{array}$ & $\begin{array}{c}\cdots \\
\underline{S M A}\end{array}$ & SAM & NS & NS & NS & $\underline{\underline{S A M}}$ & $\begin{array}{c}\cdots \\
\text { SAM }\end{array}$ & NS \\
\hline Peloscolex gabrielli & $\begin{array}{c}\cdots \\
\text { SMA }\end{array}$ & NS & $\begin{array}{c}\cdots \\
\text { SMA }\end{array}$ & $\begin{array}{c}\cdots \\
\text { SMA }\end{array}$ & $\begin{array}{c}\cdots \\
\text { SMA }\end{array}$ & NS & NS & $\begin{array}{c}\cdots \\
\text { SAM }\end{array}$ & NS \\
\hline Polydora ligni & $\begin{array}{c}\cdots \\
\underline{S M A}\end{array}$ & NS & $\begin{array}{l}\cdots \\
\text { SMA }\end{array}$ & $\begin{array}{c}\cdot \\
\text { SMA }\end{array}$ & $\begin{array}{c}\cdots \\
\underline{S M A}\end{array}$ & NS & NS & $\underline{\text { SMA }}$ & $\begin{array}{c}\ddot{\mathrm{SMA}} \\
\underline{\mathrm{S}}\end{array}$ \\
\hline Hobsonia florida & NS & NS & NS & NS & NS & NS & + & NS & NS \\
\hline Scoloplos fragilis & $\begin{array}{c}\cdots \\
\text { SMA }\end{array}$ & NS & $\ddot{M} \underline{M}$ & NS & NS & NS & NS & $\stackrel{\cdot}{\underline{S M A}}$ & $\begin{array}{c}\bullet \\
\text { SMA }\end{array}$ \\
\hline Eteone heteropoda & NS & $\stackrel{\bullet}{\text { SMA }}$ & $\begin{array}{c}\cdots \\
\text { SMA }\end{array}$ & NS & NS & NS & NS & NS & NS \\
\hline Nereis virens & $\begin{array}{c}\ddot{\mathrm{SMA}} \\
\underline{\mathrm{S}}\end{array}$ & NS & NS & + & NS & NS & $\stackrel{\cdots}{\text { SMA }}$ & $\stackrel{\cdot}{\underline{S A M}}$ & NS \\
\hline Scolecolepides viridis & + & NS & + & + & + & NS & $\begin{array}{c}\ddot{ } \\
\text { SAM }\end{array}$ & $\overline{N S}$ & + \\
\hline Spio setosa & NS & NS & + & + & + & + & NS & NS & NS \\
\hline Saccoglossus kowaleski & + & + & + & + & NS & + & + & $\begin{array}{c}\cdot \\
\mathrm{SAM} \\
\end{array}$ & NS \\
\hline Gemma gemma & $\ddot{\text { SMA }}$ & $\underline{\mathrm{SMA}}$ & NS & + & NS & + & $\begin{array}{c}\cdots \\
\underline{S M A}\end{array}$ & NS & $\begin{array}{c}\cdots \\
\underline{S M A}\end{array}$ \\
\hline Microdeutopus anomalus & + & NS & NS & NS & NS & NS & NS & NS & NS \\
\hline Corophium insidiosum & NS & NS & NS & NS & NS & NS & NS & + & NS \\
\hline Gammarus mucronatus & + & NS & NS & + & NS & NS & NS & NS & NS \\
\hline Edotea triloba & + & NS & NS & NS & NS & + & + & $\underline{\mathrm{MSA}}$ & NS \\
\hline Total density & $\begin{array}{c}\cdots \\
\underline{\mathrm{SMA}}\end{array}$ & NS & $\underline{\text { SMA }}$ & NS & NS & NS & $\begin{array}{l}.0897^{1} \\
\text { SAM }\end{array}$ & $\begin{array}{l}.0728^{1} \\
\text { SAM }\end{array}$ & $\begin{array}{c}\cdot \\
\text { SAM }\end{array}$ \\
\hline
\end{tabular}

recolonization from May through July 1979 in mud plots was higher than in sand plots. In July the difference was significant at $p<.05$, but in May and June the trend was significant only at $p<.08$ and $p<.07$, respectively.

Besides similarity between ambient and recolonization densities, patterns of between-station and between-season variability in total density were also similar. Seasonal variability progressively decreased from SI to SIII for ambient and experimental abundances and between-station differences were equivalent on the basis of where peak ambient and recolonization densities were found during a particular time period.

\section{Opportunism}

Initial responses of infauna to disturbance may be determined by the availability of colonists, or by life history features which enable a species to preferentially settle into and exploit disturbed habitats (i.e. opportunism). Results in Table 3 can be used to analyze which species behaved in an opportunistic manner. Opportunism was defined as a species significantly increasing its population size above ambient levels following a disturbance. One assumption in this analysis is that maximum responses would be detected after the 4 to $6 \mathrm{wk}$ sampling periods. This was tested in 
the June and July 1978 samples, and maximum densities were found after $4 \mathrm{wk}$, July, rather than $2 \mathrm{wk}$, June. Thistle (1980) has used this type of comparison to assess exploitation of small-scale disturbances by harpacticoid copepods, while other workers (e.g. Grassle and Grassle, 1974; McCall, 1977) have analyzed species responses on the basis of life history features.

Of those species which recolonized the plots in relatively high numbers, only Polydora ligni exhibited densities that were significantly higher than ambient levels after most sampling periods (Table 3, Fig. 3 and 6). This spionid has been characterized as an opportunistic species in other studies (Grassle and Grassle, 1974; Simon and Dauer, 1977; Pearson and Rosenberg, 1978). In contrast, responses of Streblospio benedicti and Capitella spp., also characterized as opportunists (e.g. Grassle and Grassle, 1974; McCall, 1977), were not significantly different from ambient population densities during most of the study period, and at times their responses were significantly below ambient densities (Table 3, Fig. 3 and 6).

Peloscolex gabriellae also colonized the plots in high numbers but these responses were always either significantly lower or not significantly different from ambient levels. For species which responded at moderate or low levels, there were few significant differences in population densities between experimental and ambient sediments (e.g. Hobsonia florida, Scoloplos fragilis, Microdeutopus gryllotalpa, Gammarus mucronatus and Edotea triloba), or recolonization densities were significantly below ambient densities, (e.g. Gemma gemma and Scoloplos fragilis) (Table 3). However, there were cases when species with relatively low recolonization densities responded at levels which were significantly greater than ambient population levels (Eteone heteropoda in July and August 1978 , and Nereis virens and Scolecolepides viridis in May 1979).

\section{DISCUSSION}

Similar to other studies describing estuarine softbottom benthos (e.g. Sanders et al., 1965; Boesch, 1973, 1977; Santos and Simon, 1974; Watling, 1975; Boesch et al., 1976), Alewife Cove's infauna displayed spatial and temporal variation in ambient community structure. Species responses to controlled disturbance were also highly variable. In addition, patterns of recolonization were usually synchronous with, and in the same direction as, changes in ambient population levels within the estuary. If ambient populations are experiencing high rates of expansion then the production and supply of potential colonists is also high, and disturbed habitats can be recolonized at high rates. In this manner, simultaneous ambient population expan- sion and high recolonization can be realized. However, Hannan (1981) has shown that availability of larvae for recruitment does not necessarily determine settlement', and in this study there were several cases when this relationship did not occur (e.g. Capitella spp. at SII in June and July 1978). These differences are addressed in a companion paper (Zajac and Whitlatch, 1982)

Due to the apparent relationship between ambient and recolonization dynamics, variability in recolonization may be explained by abiotic and biotic factors affecting ambient dynamics, and hence the production and supply of colonists. For example, most of the species found during this study are surface- or nearsurface deposit feeders, and their food resources would be affected by processes such as sedimentation, resuspension and transport of particulate organic matter (Rhoads, 1973; Tenore, 1977; Wolff, 1977). Various results from this study suggest that levels of food resources may be critical, including very high numbers of individuals per core, differences in density between ambient sediments and experimental plots, and a species pool whose members have overlapping food resource utilization patterns (Whitlatch, 1980).

In Alewife Cove, sedimentation, resuspension and pulses of allocthonous organic inputs fluctuate considerably on a seasonal and areal basis (Table 1). During the study, the strongest seasonal pulse of sedimentation in the middle (SII) and upper (SIII) basins of the Cove occurred in the spring due to increased freshwater inputs and ice melt (Welsh and Whitlatch, 1980). Sedimentation peaked in the area of SII in March 1979, just after the thaw, coinciding with the significant increases in ambient and experimental densities found after April and May in this area and SI. Sedimentation peaked later in the spring at SIII (July 1979, Welsh and Whitlatch, 1980), coinciding with increases in ambient and recolonization densities in this area. This pattern suggests that with the onset of reproductive activity, likely related to temperature (e.g. Clark 1979), there is a concomitant increase in the supply of food resources, perhaps increasing juvenile and adult survival and/or providing adequate resources to sustain a significant increase in larval production. Of the 16 species analyzed, 14 reached maximum ambient and experimental population densities during the spring and early summer (Fig. 3 and 6). Many of the individuals sampled at this time were juveniles (personal observations), indicating increased reproductive activity.

During the remainder of the year, freshwater runoff was sporadic, causing sedimentation and flocculation associated with the mixing zone to vary (Welsh and Whitlatch, 1980). There was, however, a significant positive correlation between freshwater flow and sedimentation in the upper basin of the estuary (Welsh 
and Whitlatch, 1980). Relatively high amounts of rainfall during October and November 1978 increased freshwater inputs into this area and sedimentation rates also increased. Ambient infaunal densities and recolonization increased significantly in this area during the fall and early winter relative to SI and SII. This may also explain why there were more temporally stable infaunal densities at SIII.

These correlations suggest sedimentation and resuspension, as mediated by water flow, affected potential food resources for the benthos and influenced ambient community dynamics and recolonization. Sedimentation at SI was not studied but it is probable that similar effects take place in this area of the estuary.

Gross sediment characteristics were not found to exert an overwhelming influence on recolonization, suggesting that between-site differences in ambient dynamics were independent of sedimentary factors. Most species in the estuary were eurytopic with respect to sediment composition. Sediment effects were observed only at times of high recolonization (e.g. spring and early summer), when mud plots usually contained higher densities of infauna than sand plots. Muddy sediments may have more available food resources (e.g. Whitlatch, 1980), and Thistle (1981) has suggested that infaunal species may respond to resource conditions generated by a disturbance, as opposed to a reduction of their competitors.

The physical and biological processes discussed are by no means the only factors that could cause variations in responses to disturbance. They are, however, examples of how fluctuations in physical factors, and their effects on estuarine infauna, can account for the spatial and temporal fluctuations observed in this study. Patterns of benthic recolonization have been shown to be variable in other studies (e.g. Dauer and Simon, 1976; Guerin and Masse, 1976; Richter and Sarnthien, 1977; Santos and Simon, 1980 b). These variable responses to disturbance, because of their prevalance, constitute a 'pattern' which should be incorporated into hypotheses concerning estuarine and marine recolonization.

Much of the theoretical focus has been on species adaptive strategies, especially in relation to life history characteristics (Grassle and Sanders, 1973; Grassle and Grassle, 1974; McCall, 1977; Pearson and Rosenberg, 1978; Santos and Simon, 1980 b; Thistle, 1981). A central concept is that species with r-selected life history traits have adapted to respond in an opportunistic fashion following a disturbance, and will dominate the initial stages of succession (e.g. Grassle and Grassle, 1974; McCall, 1977). Several of the species (Strebolspio benedicti, Polydora ligni and Capitella spp.) found in Alewife Cove have been designated as opportunists in previous studies (see Pearson and Rosenberg, 1978).
However, only Polydora ligni displayed opportunistic responses by significantly increasing its population levels in the experimental plots above ambient levels. Streblospio benedicti and Capitella spp. responded in high densities during a number of exposure periods, similar to responses observed in other studies, but relative to ambient population levels there were few indications of exploitation. Several species (Eteone heteropoda, Nereis virens, Scoloecolepides viridis) exhibited opportunistic responses even thouh their densities were relatively low. (Their life history traits would probably not be characterized as r-selected according to current hypotheses.) Consequently, the species in Alewife Cove, which are typically found in estuarine environments (e.g. Boesch, 1973; Watling, 1975; McCall, 1978), generally did not exhibit opportunistic responses to disturbances of the scale simulated by the experimental plots. Rather, a wide range of responses was exhibited by all the species.

Our results suggest that the extent of a species recolonization may be primarily dependent on ambient population fluctuations. Large increases in ambient populations during the spring and summer coincided with peak recolonization episodes, while lower ambient densities in the fall and winter coincided with decreased responses to disturbance. Further, classification analyses indicated that similarities in species responses were based on when and where the greatest recolonization took place, not on the overall magnitude of the response (Fig. 7). Dependence on local ambient dynamics is reflected in the fact that ambient species groups were almost identical to those formed from the recolonization data (Fig. 4 and 7). In addition, species included within most of the groups have varied life histories (see Olive and Clark, 1978 for polychaetes; Nelson, 1980 for amphipods), suggesting that initial dynamics of recolonization may depend more on spatial and temporal environmental variability than the responses of species with a particular suite of life history characteristics. Designation of infaunal species as 'opportunistic' may be highly dependent on historical features of a particular habitat.

Acknowledgements. We thank B. L. Welsh, F. C. Dobbs, J. Weinberg, V. Starczak, S. Malinowski and C. Katz for stimulating discussions and suggestions during the course of this study. R. Degoursey and A. Lima provided valuable technical assistance and we appreciate the critical reviews of D. Thistle and of 2 anonymous reviewers. Thanks to F. Z . Calafiore for providing a helping hand. This work was supported in part by grants from The State of Connecticut Department of Environmental Protection (to RBW) and The Sigma Xi Foundation (to RNZ). This is Contribution No. 146 of the Marine Sciences Institute, University of Connecticut. 


\section{LITERATURE CITED}

Arntz, W. E, Rumohr, H. (1978). The Benthosgarten: field experiments on benthic colonization on the Western Baltic. II. Subsequent successional stages. Kieler Meeresforsch. 4: 97

Boesch, D. F. (1973). Classification and community structure of macrobenthos in the Hampton Roads area, Virginia. Mar. Biol. 21: 226-244

Boesch, D. F. (1977). A new look at the zonation of benthos along the estuarine gradient. In: Coull, B. C. (ed.) Ecology of marine benthos. University of South Carolina Press, Columbia, pp. 245-266

Boesch, D. F., Wass, M. L., Virnstein, R. W. (1976),. The dynamics of estuarine benthic communities. In: Wiley, $\mathrm{M}$. (ed.) Estuarine processes. Academic Press, New York, pp. 177-196

Clark, R. B. (1979). Environmental determination of reproduction in polychaetes. In: Stancyk, S. E. (ed.) Reproductive ecology of marine invertebrates. University of South Carolina Press, Columbia, pp. 107-122

Connell, J. H., Slatyer, R. O. (1977). Mechanisms of succession in natural communities and their role in community stability and organization. Am. Nat. 111: 1119-1144

Conner, W. G., Simon, J. L. (1979). The effects of oyster shell dredging on an estuarine benthic community. Estuar. coast. mar. Sci. 9: 749-758

Dauer, D. M., Simon, J. L. (1976). Habitat expansion among polychaetous annelids repopulating a defaunated marine habitat. Mar. Biol. 37: 169-177

Dean, D., Hasking, H. H. (1964). Benthic repopulation of the Raritan River estuary following pollution abatement. Limnol. Oceanogr. 9: 551-563

Dixon, W. J., Brown, M. B. (1979). Biomedical computer programs P-Series, University of California Press, Berkeley

Grassle, J. F., Sanders, H. L. (1973). Life histories and the role of disturbance. Deep Sea Res. 20: 643-659

Grassle, J. F., Grassle, J. P. (1974). Opportunistic life histories and genetic systems in marine benthic polychaetes. J. mar. Res. 32: 253-284

Grassle, J. F., Grassle, J. P. (1977). Temporal adaptations in sibling species of Capitella. In: Coull, B. C. (ed.) Ecology of marine benthos. University of South Carolina Press, Columbia, pp. 177-190

Guerin, J. P., Masse, H. (1976). Experimental and methodological study of macrofaunal species recruitment in soft-bottoms. Tethys 8 : $151-168$

Hannan, C. A. (1981). Polychaete larval settlement: correspondence of patterns in suspended jar collectors and in the adjacent natural habitat in Monterey Bay, California. Limnol. Oceanogr. 26: 159-171

Herring, J. P. R. (1978). The effects of a small estuary on the processing of freshwater runoff and tidal water. Masters thesis, University of Connecticut

Johnson, R. G. (1973). Conceptual models of benthic communities. In: Schopf, T. J. M. (ed.) Models in paleobiology Freeman Cooper and Company, San Francisco, pp. $148-159$

Leppakowski, E. (1969). Transitory return of the benthic fauna of the Borholm Basin after extermination by oxygen insufficiency. Cah. Biol. mar. 10: 163-172

McCall, P. L. (1977). Community patterns and adaptive strategies of the infaunal benthos of Long Island Sound. J. mar. Res. 35: 221-266

McCall, P. L. (1978). Spatial-temporal distributions of Long Island Sound infauna: the role of bottom disturbance in a nearshore habitat. In: Wiley, M. L. (ed.) Estuarine interactions. Academic Press, New York, pp. 191-219

Nelson, W. G. (1980). Reproductive patterns of gammaridean amphipods. Sarsia 65: 61-71

Olive, P. J. W., Clark, R. B. (1978). Physiology of reproduction. In: Mill, P. J. (ed.) Physiology of annelids. Academic Press, London, pp. 271-368

Paine, R. T., Levin, S. A. (1981). Intertidal landscapes: disturbances and the dynamics of pattern. Ecol. Monogr. 51: $145-178$

Pearson, T. H., Rosenberg, R. (1978). Macrobenthic succession in relation to organic enrichment and pollution of the marine environment. Oceanogr. mar. Biol. A. Rev. 16: 299-311

Rhoads, D. C. (1973). The influence of deposit-feeding benthos on water turbidity and nutrient recycling. Am. J. Sci. 273: 1-22

Rhoads, D. C., Aller, R. C., Goldhaber, M. B. (1977). The influence of colonizing benthos on physical properties and chemical diagenesis of the estuarine seafloor. In: Coull, B. C. (ed.) Ecology of the marine benthos. University of South Carolina Press, Columbia, pp. 113-138

Rhoads, D. C., McCall, P. L., Yingst, J. Y. (1978). Disturbance and production on the estuarine seafloor Am. Sci. 66: $557-586$

Richter, W., Sarnthien, M. (1977). Molluscan colonization of different sediments on submerged platforms in the western Baltic Sea. In: Keegan, B. F., Ceidigh, P. O., Boaden, P. J. S. (eds.) Biology of benthic organisms. Pergamon Press, New York, pp. 531-539

Rumohr, H. (1978). The „Benthosgarten“: field experiments on benthic colonization in the Western Baltic. I. Initial colonization. Kieler Meeresforsch. 4: 96

Sanders, H. L., Mangelsdorf, Jr., P. C., Hampson, G. R. (1965). Salinity and faunal distribution in the Pocasett River, Massachusetts. Limnol. Oceanogr. 10: R216-R229

Sanders, H. L., Grassle, J. F., Hampson, G. R., Morse, L. S., Garner-Price, S., Jones, C. C. (1980). Anatomy of an oil spill: long-term effects from the grounding of the barge Florida off West Falmouth, Massachusetts. J mar. Res. 38: $265-380$

Santos, S. L., Simon, J. L. (1974). Distribution and abundance of the polychaetous annelids in a south Florida estuary. Bull. mar. Sci. 24: 669-689

Santos, S. L., Simon, J. L. (1980a). Marine soft-bottom community establishment following annual defaunation: larval or adult recruitment? Mar. Ecol. Prog. Ser. 2: 235-241

Santos, S. L., Simon, J. L. (1980b). Response of soft-bottom benthos to annual catastrophic disturbance in a south Florida estuary. Mar. Ecol. Prog. Ser. 3: 347-355

Simon, J. L., Dauer, D. M. (1977). Reestablishment of a benthic community following natural defaunation. In: Coull, B. C. (ed.) Ecology of marine benthos. University of South Carolina Press, Columbia, pp. 139-154

Snedecor, G. W., Cochran, W. G. (1974). Statistical methods, Iowa State University Press, Ames

Tenore, K. R. (1977). Food chain pathways in detrital feeding benthic communities: a review, with new observations on sediment resuspension and detrital recycling. In: Coull, B. C. (ed.) Ecology of marine benthos. University of South Carolina Press, Columbia, pp. 37-53

Thistle, D. (1980). The response of a harpacticoid copepod community to a small-scale disturbance. J. mar. Res. 38 : 381-395

Thistle, D. (1981). Natural physical disturbances and communities of marine soft bottoms. Mar. Ecol. Prog. Ser, 6: 223-228 
Watling, L. (1975). Analysis of structural variations in a shallow estuarine deposit feeding community. J. exp. mar. Biol. Ecol. 19: 275-313

Welsh, B. L., Herring, J. P., Read, L. M. (1978). The effects of reduced wetlands and storage basins on the stability of a small Connecticut estuary. In: Wiley, M. L. (ed.) Estuarine interactions. Academic Press, New York, pp. 381-401

Welsh, B. L., Whitlatch, R. B. (1980). A study of Alewife Cove: its siltation, eutrophication and hydraulic character. Final Report to the Commissioner of Environmental Protection, Department of Environmental Protection, State of Connecticut. Parts I, II and III

Whitlatch, R. B. (1980). Patterns of resource utilization and coexistence in marine intertidal deposit-feeding communities. J. mar. Res. 38: 743-765

Whittaker, R. H., Levin, S. A. (1977). The role of mosaic phenomenon in natural communities. Theor. Pop. Biol. 12 $117-139$
Wolff, W. J. (1977). A benthic food budget for the Grevelingen Estuary, The Netherlands, and a consideration of the mechanisms causing high benthic secondary production in estuaries. In: Coull, B. C. (nd) Ecology of marine benthos. University of South Carolina Press, Columbia, pp. $267-280$

Wolff, W. J, Sandee, A. J. J., de Wolf, L. (1977). The development of a benthic ecosystem. Hydrobiologia 52: 107-115

Woodin, S. A. (1981). Disturbance and community structure in a shallow water sand flat. Ecology 62: 1052-1066

Zajac, R. N. (1981). Successional and ambient infaunal community dynamics in a New England estuary. Masters thesis. The University of Connecticut

Zajac, R. N., Whitlatch, R. B. (1982). Responses of estuarine infauna to disturbance. II. Spatial and temporal variation of succession. Mar. Ecol. Prog. Ser 10: 15-17

This paper was submitted to the editor; it was accepted for printing on June 3, 1982 